This is an electronic reprint of the original article. This reprint may differ from the original in pagination and typographic detail.

Author(s): Hänninen, Nora; Karjaluoto, Heikki

Title: $\quad$ Environmental values and customer-perceived value in industrial supplier relationships

Year: $\quad 2017$

Version:

Please cite the original version:

Hänninen, N., \& Karjaluoto, H. (2017). Environmental values and customer-perceived value in industrial supplier relationships. Journal of Cleaner Production, 156, 604-

613. https://doi.org/10.1016/j.jclepro.2017.04.081

All material supplied via JYX is protected by copyright and other intellectual property rights, and duplication or sale of all or part of any of the repository collections is not permitted, except that material may be duplicated by you for your research use or educational purposes in electronic or print form. You must obtain permission for any other use. Electronic or print copies may not be offered, whether for sale or otherwise to anyone who is not an authorised user. 


\section{Accepted Manuscript}

Environmental values and customer-perceived value in industrial supplier relationships

Nora Hänninena, Heikki Karjaluotoa

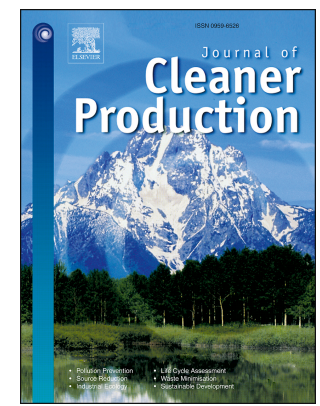

PII:

S0959-6526(17)30799-0

DOI:

10.1016/j.jclepro.2017.04.081

Reference: JCLP 9436

To appear in: Journal of Cleaner Production

Received Date: 29 December 2016

Revised Date: 16 March 2017

Accepted Date: 12 April 2017

Please cite this article as: Hänninena N, Karjaluotoa $\mathrm{H}$, Environmental values and customerperceived value in industrial supplier relationships, Journal of Cleaner Production (2017), doi: 10.1016/ j.jclepro.2017.04.081.

This is a PDF file of an unedited manuscript that has been accepted for publication. As a service to our customers we are providing this early version of the manuscript. The manuscript will undergo copyediting, typesetting, and review of the resulting proof before it is published in its final form. Please note that during the production process errors may be discovered which could affect the content, and all legal disclaimers that apply to the journal pertain. 


\title{
Environmental values and customer-perceived value in industrial supplier relationships
}

Nora Hänninen $_{\mathrm{a}}$ and Heikki Karjaluoto

aJyväskylä University School of Business and Economics

Postal address: P.O. Box 35, FI-40014 University of Jyväskylä, Finland

Correspondence to Nora Hänninen

E-mail address: nora.t.c.haenninen@jyu.fi

\section{Wordcount: 9767}

\begin{abstract}
This study addresses a gap in the research on supply channel management by integrating environmental values and value creation in the context of buyer-supplier relationships. This study has two objectives: (i) to explore the environmental values structure of industrial customers, and (ii) to test the effect of environmental values on overall value perceptions. The effect of customer's environmental values on the supplier's environmental image and customer-perceived value is tested with structural equation modeling using the PLS method. The empirical analysis is based on a global sample of industrial companies that have a high impact on the environment $(n=121)$. Key findings of this study are that (i) customer environmental values consist of three domains: corporate stance, operational awareness and environmental competence; (ii) environmental values of the customer have an effect on supplier assessment in a competitive market; and (iii) industrial suppliers should contribute to customers' overall value expectations by building an image that is based on environmental competitiveness.
\end{abstract}

Keywords: Environmental values; Customer-perceived value; Industrial relationships, Environmental supplier and survey

\section{Introduction}

Concern for the natural environment and sustainability are topics that every company has to address in the current business and societal contexts. At the same time, business organizations mainly aim at satisfying market and stakeholder needs (Heikkurinen and Bonnedahl, 2013) whereas responsibilities toward society and the natural environment may still be considered secondary (Smith, 2009). Despite the prevailing priority of economic goals over other values in business, the literature suggests that addressing concerns about the environment may help companies achieve environmental and economic value. Business and environmental goals may be integrated so that both performance objectives are reached simultaneously, benefiting also the wider supply chain (Park et al., 2010). Researchers have suggested that environmentally oriented improvements enhance economic, operational and organizational performance (Green et al., 2012). More specifically, environmental improvements have led to cost reduction through more efficient resource use (Severo et al., 2015) and increase in sales and profits (Lee and Rhee, 2007). Environmental performance and activities also have an impact on a company's strategic position in the marketplace (Zhao et al., 2015). Research has shown that the performance benefits of greening are realized only 
when the whole supply chain gradually shifts toward more sustainable practices (Rao and Holt, 2005). Therefore, the various drivers and effects of environmental efforts are best understood as an inter-organizational topic within a supply chain (Hall, 2000).

In the context of supply channel management, customers are repeatedly found to be the key driver of greening (Laari et al., 2016a; Yen and Yen, 2012). The main outcomes companies expect for their environmental efforts are customer satisfaction and an improved image among customers (Ageron et al., 2012). A positive environmental image enhances a firm's competitive performance (Amores-Salvadó et al., 2014; Larrán Jorge et al., 2015). From the buyer's perspective, reputation and image are major drivers of environmental purchasing (Björklund, 2011), but then again, a supplier's environmental effort is not a major selection criterion especially in the case of critical suppliers (Kovács, 2008). However, the environmental capabilities of an industrial supplier also largely affect their customers' inbound greening (Rao and Holt, 2005), and successfully addressing customers' environmental demands downstream in the chain enhances the supplier's position in the market (Junquera et al., 2012).

The literature remains inconclusive whether environmentally oriented purchasing and supply strategies truly pay off, and companies are unsure about how to gain a competitive advantage from environmental efforts, such as adopting a green supply channel management strategy (Ageron et al., 2012; Kirchoff et al., 2016). In addition, the most often reported barrier to adopting environmental practices is the perceived cost for buyers and suppliers alike (Appolloni et al., 2014; Giunipero et al., 2012; Roehrich et al., 2014). Especially in larger investment decisions, companies may use purchasing price as the key criterion even though a more expensive and more environmental solution would yield long-term cost savings (Anderson et al., 2000), leading to gaps among the company's environmental awareness, decision-making and behavioral outcomes (Zsóka, 2008). The value priorities also vary across organizations, suggesting that the metrics-based approach to environmental concern should be complemented with knowledge about the customer's environmental values in order to predict their supplier selection (Alexander et al., 2014). However, research on industrial buyer-supplier dyads does not elaborate the linkage of values and value that explains how environmental concern as a value-based motivation influences customer perceptions of supplier overall value.

Recently, scholars have called for more empirical knowledge on the role of values in decisionmaking (Alexander et al., 2014) and relationship-oriented research of customers in supply channels (Quarshie et al., 2016). Combining the aspects of environmental concern and overall supplier evaluation thus might explain how different companies apply different solutions to the conflict between seemingly exclusive economic and environmental values (Reuter et al., 2012). This study fills these gaps in the research and sets industrial buyer-supplier dyads in a value-based framework, emphasizing the identification of customers' value criteria and their effect on evaluations of suppliers (Woodruff, 1997). This study develops and tests a framework of customer's environmental values, supplier's environmental image and customer-perceived supplier value and adds to the scant value-based approach in environmentally oriented business research (Closs et al., 2011) by answering the following research questions:

What is the structure of environmental values among industrial companies that have a high impact on the environment? 
How do customers' environmental values affect perceptions of their suppliers' environmental image and perceived value?

Whereas researchers have utilized self-evaluations of suppliers regarding their environmental image and competitive advantage (Amores-Salvadó et al., 2014; Junquera et al., 2012; Larrán Jorge et al., 2015), in this study, the customer's viewpoint is adopted as a novel contribution. Customer perspective enables managerial implications that serve industrial companies both as suppliers and buyers attempting to deliver and draw superior customer value in ecological as well as economic terms.

The study proceeds as follows. First, the research questions and relevant concepts are reviewed in the existing literature and then formulated in a theoretical framework with research hypotheses. Then, the framework is tested on a global survey sample of business-tobusiness (B2B) customers operating in industries that have a high impact on the environment. The results of the statistical data analyses are presented and discussed. The study is concluded with contributions to the literature on environmental values and business relationships with managerial implications. Finally, limitations of the study are assessed, and suggestions for future research are presented.

\section{Theoretical background and research framework}

Understanding customer preferences and expectations is important in all business relationships. These preferences can be conceptualized as values that represent the morally laden judgment about the priorities of certain topics, as well as the added value in the business-oriented sense (Hall, 1989). In this study, both meanings of "value" that are theoretically distinct are used. First, environmental values represent the company's stance toward ecological concerns and the role of environmental consideration as a normative guideline in the organization's strategy and actions. Second, customer-perceived value refers to the assessment of value that is gained from the supplier relationship. Understanding the hierarchical order and interplay of values and value may explain how customers choose suppliers over others and guide the formulation of appropriate marketing strategies that respond to customers' value desires in established relationships (Woodruff, 1997). The value paradigm has been used less frequently in the studies on (environmental) supply channel management, but some researchers have reported the relevance of the paradigm in purchasing and supply relationships (O'Toole and Donaldson, 2002), as well as in the wider supply chain (Park et al., 2010). Knowledge about the effect of environmental values on perceived value is relevant considering that the demand for environmental improvements often originates from downstream customers in the supply chain (Hall, 2000). Also, industrial suppliers may choose a differentiation or price premium strategy based on sustainability competitiveness (Laari et al., 2016b), but the willingness of industrial customers to invest in the potentially more expensive environmental technologies depends on various factors, such as their own environmental strategy (Paulraj, 2009) and overall economic situation (Giunipero et al., 2012).

\subsection{Environmental values}

External regulations and pressures provide the minimum requirements for appropriate company behavior in terms of environmental preservation, but each business organization 
also has its own values that guide operations from the corporate-level philosophy to daily actions (Hall, 1989). A business organization consists of humans who act in different functions and positions to serve the company's overall objectives. Therefore, values affect attitudes and behavior on multiple levels, and as a consequence, mixed effects of company and individual values may be perceived in company operations (Agle and Caldwell, 1999). Often, environmentally oriented actions are implemented by influential individuals and require the support of senior-level management (Blome et al., 2014; Giunipero et al., 2012). Measuring an organization's values is challenging, and not many studies have conceptualized the environmental values of business organizations. Instead, environmental values are derived from indirect indicators such as organizational culture (Zsóka, 2008). Some researchers have used the implementation of the ISO 14000 standard as an indicator of stronger environmental values (Cantor et al., 2013; Cheng et al., 2008) or even as reflecting company core values (Hanson et al., 2004); however, other researchers have shown that standards may have little to do with the company's devotion to addressing environmental values in particular (Mueller et al., 2009). There is also empirical evidence of deficits even in the most reputable and widespread environmental standards. For example, ISO 14000 enables building a legitimate environmentally oriented front for the company while the structures and practices may not actually differ from those of non-certified companies (Mueller et al., 2009). Especially noteworthy regarding buyer-supplier relationships is that ISO 14000 does not consider n-tier suppliers (Mueller et al., 2009). Therefore, a buyer's certification indicates the existence of a minimum level of environmental interest (Junquera et al., 2012), but it does not provide information about whether environmental issues are perceived as relevant in supplier evaluation during purchasing processes.

Dembkowski and Hanmer-Lloyd (1994) used the concept of environmental consciousness and formulated a values-attitudes framework consisting of global values, domain-specific values and product attributes with situation-specific factors that together explain the environmental purchasing of individual consumers. The three-level model is an adaptation of consumers' value-attitude system by Vinson et al. (1977) that considers personal human values in general and their effect on consumption values. In Dembkowski and Hanmer-Lloyd's model, global values are related to the overall perceived importance of the environment and its protection. Domain-specific values represent the role of environmental consideration in consumption patterns. Product attributes are less central perceptions about the criticality of environmental features in a particular decision-making situation. Zsóka (2008) presents a resembling concept of environmental awareness in the industrial context that includes related knowledge, values, attitudes, willingness to act and actual behavior. Hall (1989) utilizes the continuum of strategies and tactics to illustrate the role of values and ethics in business, suggesting that company values exist at the strategic level whereas ethics is included at a tactical or action-specific level. However, as the distinction between strategic and tactical levels may be difficult to determine, an explorative approach to the topic is taken in this study, allowing strategic and tactical-level elements to be included in the construction of environmental values.

Altogether, previous literature shows that measuring environmental values in an organization necessitates a deep and broad scope of conceptualization in order to get a comprehensive picture of the phenomenon. For example, companies might report high levels of environmental consciousness and pro-environmental attitudes but have taken few actions accordingly (Kärnä et al., 2001). Or, some companies may have implemented proenvironmental practices due to external pressures, such as legislation, without possessing a 
strategic level interest towards environmental concern (Roehrich et al., 2014). Due to the lack of established conceptualization and operationalization of environmental values in the context of organizations, it is assumed from previous research that environmental values are formed as a combination of individual (employee) and organizational priorities (Agle and Caldwell, 1999) that manifest in a company's stance toward environmental issues on various levels ranging from corporate-level philosophy to concrete level such as product attributes and operations (Dembkowski and Hanmer-Lloyd, 1994; Hall, 1989). This multi-level measurement of values is suggested as a means for tapping individual differences in concrete situations of judgment and decision-making (Schwartz, 1992).

\subsection{Perceived value and environmental image}

Values are the key antecedent of supplier evaluation within a competitive field (Ulaga and Eggert, 2006). Whereas environmental values construct captures the company's stance towards ecological preservation, a business-oriented concept of value is also required to explain how environmental values influence supplier evaluation in a business relationship. In research of buyer-supplier relationships and purchasing behavior in general, the assessment of a supplier and its offering are often conceptualized with the construct of customerperceived value (or in short, perceived value). Zeithaml (1988), introducing the concept, defined perceived value as a tradeoff between benefits and sacrifices. Since then, the concept of perceived value has been widely employed to illustrate a customer's assessment of products, services and relationships in the consumer and business markets (Woodruff, 1997). Of particular importance regarding competitive advantage is a supplier's ability to provide value that addresses current customer expectations (Flint et al., 2002). A key characteristic of perceived value is its relativity, that is, perceived value is assessed in comparison with alternative or competing offerings, and provides an understanding of how buyers choose a certain product or supplier over others (Anderson et al., 2000; Ulaga and Eggert, 2006). In this study, perceived value represents the outcome assessment of the supplier's performance as perceived by the customer, formed as a combination of price and quality elements (Zeithaml, 1988). The benefit or quality dimension of perceived value typically consists of performance-related drivers, such as technical and functional quality (Bell et al., 2005; Ulaga and Chacour, 2001). In line with the previous literature, the benefit dimension of customerperceived value in this study consists of quality attributes, such as technical quality and solid performance.

Perceived value may also contain or consist of "softer" elements, such as social and image benefits (Anderson et al., 2000; Andreassen and Lindestad, 1998; Ledden et al., 2007). Image represents the benefits of a higher status that adds to the overall experience of a company in the minds of its customers and the wider social context (Ledden et al., 2007). Regarding the context of industrial supplier relationships, the image dimension seems relevant. Reputational benefits are realized in the wider supply chain by contributing to the customer's own capabilities as a supplier downward in the supply channel (Appolloni et al., 2014; Fang et al., 2008). Due to the particular interest in concerns about the environment in this study, the supplier's ability to enhance a customer's environmental performance is extracted from perceived value as a separate construct of environmental image. As a driver of customerperceived value, environmental image is considered to represent the outcome of the supplier's emphasis on environmentally oriented improvements. A supplier with a positive environmental image not only complies with stakeholder pressures and gains the minimum 
level of environmental legitimacy (Junquera et al., 2012) but also is distinguished from competitors as providing environmentally developed solutions. The literature stresses the active role of the supplier in maintaining a strategic position (Andersen et al., 2016), and building an environmentally favorable image requires communication of these benefits (Amores-Salvadó et al., 2014). Customer-perceived value is suitable for modeling the effects of environmental efforts in a business relationship because the concept represents financial and non-financial aspects, thus tapping the interplay of economic versus environmental benefits and cost in a value assessment (Reuter et al., 2012).

\subsection{The effect of environmental values on supplier image and perceived value}

Research on human values posits that values are the guiding principles that are transsituational and precede judgments and actions (Schwartz, 1992). These judgments and actions, however, also contain conflicting motivations such as personal interest versus welfare of others. In the context of business organizations, the centrality of monetary value and the instrumentality of other values explain why environmental values may not transfer into preferences and practical outcomes directly, but the decisions are a result of tradeoffs between potentially conflicting values (Reuter et al., 2012). Environmental awareness is a prerequisite for pro-environmental decision-making and behavior (Zsóka, 2008), but research has repeatedly shown that environmental consciousness and attitudes are not always manifested in actual behavior (Goh and Balaji, 2016; Liobikienè and Juknys, 2016). Altogether, the dynamic nature of values and value and the attitudinal-behavioral gap complicate predicting whether customers reward the supplier's environmental efforts by perceiving more overall value in the supplier relationship.

Previous empirical findings suggest that purchasing professionals tend to be uninterested in social responsibility issues (Drumwright, 1994) and prefer passive, compliant approaches to concerns about the environment (Preuss, 2001). Purchasing professionals also emphasize the performance-related aspects of products instead of the environmental qualities (Lindgreen et al., 2009). This preference is reasonable considering that a key task of a purchasing professional is to ensure that the largest possible value is gained from investments. The technical and monetary aspects of an offering (especially price) are always easier to demonstrate and justify than other benefits that may unfold only in a long-term assessment (Anderson et al., 2000). In this light, the negotiations between seemingly competing values in industrial purchasing are explained by intervening contextual and situational factors but also pose challenges for environmentally oriented suppliers that might promote environmentally developed solutions that are sold at a higher price but pay a return during a longer-term assessment. In the context of industrial manufacturing, environmental benefits may often be linked to monetary issues (lower resource usage is economic and environmental) so it may be easier for suppliers to demonstrate that environmental benefits co-occur with resource savings, resulting in compatibility of ecological and economic value. Despite the hindrances of pro-environmental purchasing behavior, it may be logically assumed that customers who perceive themselves as having stronger environmental values expect their chosen suppliers to address these issues and if so, perceive more value in their supplier (Paulraj, 2009). The first research hypothesis is formulated accordingly: 
H1: A customer's environmental values are positively related to perceived value of the supplier.

Previous research shows that an environmental image is a major driver of environmental purchasing for industrial customers (Björklund, 2011). Yen and Yen (2012) list the commitment of senior management, supplier collaboration and customer collaboration as key drivers of environmental purchasing. A supplier's environmental image also contributes to the buyer's environmental status downstream in the value chain (Appolloni et al., 2014). Reflecting on these findings, it may be assumed that an environmentally motivated customer seeks environmental benefits upstream from the supplier relationship. Therefore, environmentally-oriented customers appreciate the environmental efforts of their supplier and rate their environmental image higher, leading to the second hypothesis:

H2: The more environmentally oriented a customer is, the more favorably the supplier's environmental image is regarded.

Image is found to be a strong predictor of perceived value (Ciavolino and Dahlgaard, 2007), and a strategically established status yields further favorable outcomes in the supplier evaluation (Andersen et al., 2016). Researchers have shown that a supplier's image contributes to the formation of overall perceived value either as a separate construct (Ciavolino and Dahlgaard, 2007) or as belonging to perceived value (Ledden et al., 2007). In environmental supply channel management, environmental image has been shown to affect firm performance measured in economic terms (Amores-Salvadó et al., 2014) and in the form of competitive advantage (Junquera et al., 2012; Larrán Jorge et al., 2015). Following the previous findings about the favorable impact of positive image on perceived overall value, it is hypothesized that:

H3: A supplier's environmental image is positively related to perceived value of the supplier.

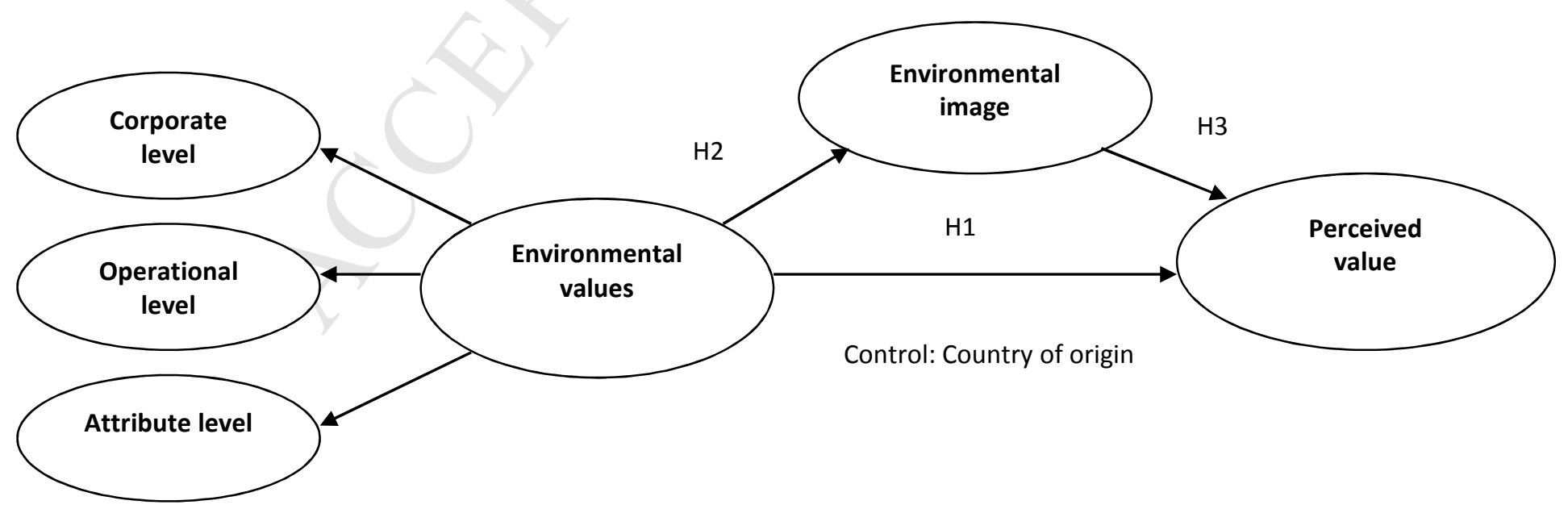


Fig. 1. The conceptual framework.

The model was controlled for the effects of country of origin. It was assumed that companies located in higher-income economies emphasize the supplier's environmental image more as research suggests that economic development and environmental development is positively associated (Dasgupta et al., 2001).

\section{Research design}

This study employs a quantitative approach. The following section presents the design of the empirical research. The operationalization of the theoretical framework, the sampling and data collection procedures and the method of analysis are explained.

\subsection{Measures}

Based on theories of values in business organizations (Agle and Caldwell, 1999; Hall, 1989), environmental values were posited to exist and to be manifested on different levels. The structure of environmental values was assumed to be a hierarchical collection of values and related behavior from global beliefs to product attributes (Dembkowski and Hanmer-Lloyd, 1994) No established scales for measuring environmental values existed, so items were adapted from previous studies and developed in discussions with industry experts to best suit the empirical context. Measures were formulated by following previous empirical research on corporate environmental values and strategies (Banerjee, 2001; Kärnä et al., 2003), environmental management (Lee and Rhee, 2007) and green supply chain management, including the viewpoint of customer cooperation (Zhu et al., 2005). To enable testing for the control effects of external pressures (Banerjee et al., 2003), government regulation and customer cooperation were added as potential value drivers (Banerjee et al., 2003; Zhu et al., 2005). All items were measured on seven-point Likert scales.

Perceived value was measured on a seven-point multi-item scale that tapped the traditional benefit dimensions of perceived value as consisting of solid performance, reliability and product quality (Sweeney and Soutar, 2001; Ulaga and Eggert, 2006). Items measuring the supplier's environmental image were adapted from Fang et al.'s (2008) new product value scale that emphasizes the supplier's ability to deliver improvements in the product and its performance. In addition, an item regarding the supplier's overall environmental reputation was adapted from the scale of the general company image as measured in Ledden et al.'s (2007) work. In most previous research on environmental supply channel management, the environmental image has been assessed by the suppliers themselves (Amores-Salvadó et al., 2014; Larrán Jorge et al., 2015; Junquera et al., 2012), but in this study, the supplier image was assessed by the customer in order to understand the impact on the overall value perception in a particular relationship. Perceived value and environmental image were measured in comparison to competitors, as that is considered the most meaningful way of assessing value as a critical determinant of supplier choice in a competitive market (Ulaga and Eggert, 2006). The list of measures is found in the Appendix. 


\subsection{Sampling and data gathering}

The dataset was gathered from customers of three Finnish industrial companies that manufacture and supply industrial equipment and solutions in industries that have a high impact on the environment: pulp and paper, and metals and minerals processing. Two of the supplier companies are listed on the Helsinki stock exchange and operate worldwide. The third operates mainly in Finland. The customer companies are located worldwide. The sample was collected in cooperation with the supplier companies. The representatives of the supplier companies compiled the groups of target respondents from the suppliers' customer databases, resulting in a geographically and economically diverse sample of companies in the manufacturing and process industries. Empirical research has shown that individuals, typically managers in the case of business organizations, are the most important actors that have an actual effect on company policies and the implementation of values into actions (Drumwright, 1994; Yen and Yen, 2012). Therefore, the survey instrument was targeted at managers who have power over supplier decisions and who are also sufficiently knowledgeable about their company operations in general. With the help of the supplier company managers, the survey reached representatives of customer companies who qualified as informants. On one hand, the non-randomized sampling technique compromised the generalizability of the results. On the other hand, customer-perceived value and supplier image as competition-based phenomena necessitated a relationship-specific approach. The involvement of supplier companies was also hoped to make survey participation worthwhile to all target respondents and not only those who are particularly interested in the topic.

The survey was conducted electronically in the autumn of 2009. Supplier company representatives emailed their customers a cover letter that explained the purpose of the survey as part of a larger scientific research project where the interest was in getting more knowledge about the values and preferences of industrial customers and their perceptions regarding supplier relationships. The respondents were asked to participate in the web-based survey by following a link in the cover email. There were three language options: Chinese, English and German. The option of participating in a lottery for a heart rate monitor was offered to encourage the target respondents to answer. To minimize the potential biasing effect of socially desirable answering style, the respondents' anonymity was guaranteed, and the survey instrument allowed respondents to leave items, such as demographic information, unanswered. Only the academic research team had access to the survey data, and the anonymity and confidentiality of the responses were emphasized in the cover letter. The survey instrument also included more topics and items than those employed and presented in this study, making the hypothesized connections between constructs less obvious to the respondent. However, as one of the objectives of this study was to contribute to the suppliers' knowledge about their customers' values, the socially desirable response style may not actually bias the results but instead, provide useful information about the normative and cultural context that frames customers' actions (Fisher and Katz, 2000). The early and late responses were compared to address non-response bias (Armstrong and Overton, 1977), and no statistically significant differences were found in the data $(p<0.05)$.

\subsection{Method of analysis}

The survey data were analyzed quantitatively by applying factor analysis and structural equation modeling. First, explorative factor analysis was executed with IBM SPSS Statistics 22 software on all variables in order to assess the reliability and validity of the constructs. To 
confirm the suggested factor structure and test the hypothesized relationships between the latent variables, analysis of the latent variables followed the two-step procedure suggested by Anderson and Gerbing (1988). Confirmatory factor analysis was performed, and the structural model was tested with partial least squares (PLS) structural equation modeling with SmartPLS 3.0 (Ringle et al., 2014). PLS was chosen because it is suitable for exploratory studies that use small sample sizes and serve as nonparametric samples (Hair et al., 2013, p. 19). All constructs were treated as reflective latent variables. Customers' environmental values were measured as a reflective-reflective second-order factor.

To address common method bias, a typical problem of self-reported data, precautions were taken throughout the research process following Podsakoff et al. (2003). Respondents were allowed to answer anonymously, data were gathered on multi-item scales and items were mixed up in the survey instrument. We included a common method factor in the PLS model and compared its loadings to the indicator loadings (see Liang et al., 2007). The results showed that most of the method factor loadings were statistically insignificant and the indicators' substantive variances were substantially greater $(0.75)$ than their method variances (0.008). Thus, common method bias is unlikely to be a serious concern in this study.

\section{Results}

The survey received 121 answers. The background information on the informants' companies included country of origin, annual turnover and length of relationship with the particular supplier. The respondents all worked in executive positions for different companies, and they represented companies in 25 countries of origin; most were from Germany (17\%), China (13\%), Finland (13\%), the UK (9\%), South Africa (8\%) and the US (6\%). The mean length of the business relationship with the particular supplier was 18 years, which illustrates the longterm nature of industrial relationships and the lengthy investment cycles of manufacturing equipment. The median annual turnover of the respondents' companies was $€ 42$ million. In the analysis, the customer company's country of origin was transformed into a dummy variable that was given the value 2 if the company was situated in a high-income economy and 1 if it was based elsewhere. The distinction was based on the World Bank's (2014) classifications.

\subsection{Exploratory factor analysis}

The Kaiser-Meyer-Olkin (KMO) measure of sampling adequacy (0.856), and Bartlett's test for sphericity $(p<0.000)$ gave a good grounding for exploratory factor analysis of the items measuring environmental values. Exploratory factor analysis was conducted with principal axis factoring and the varimax rotation, suggesting three factors that together explained $56 \%$ of the variance in the items that measured customer environmental values. Items with extracted communalities lower than .30 were excluded from further analyses. The first factor explained $21.7 \%$, the second factor $19.5 \%$ and the third factor $15.0 \%$ of the variance. The first factor was named "environmental awareness," reflecting the company as an environmentally conscious aggregate that is aware of its effect on the environment and takes actions that aim at preserving natural resources. The second factor was named "environmental competence" because it reflected the company's perceived potential of gaining marketing advantages from its core capabilities, such as the product and production technology. The third factor was comprised of environmental issues in the company's philosophy and strategic-level decisionmaking, which resulted in its naming of "corporate stance." 


\subsection{Measurement model}

Inspection of factor loadings (all $>0.68, p<0.001$ ) and Cronbach's alphas (all greater than 0.70 ) suggested sufficient construct reliability (Table 1). Convergent validity was assessed by examining the composite reliability and the average variance extracted (AVE). The composite reliabilities exceeded the threshold of 0.80 (Fornell and Larcker, 1981). Although the AVE of the second-order environmental values construct was below the generally accepted threshold of 0.50 , the AVE values of the first-order constructs were adequate. The outer and inner variance inflation factors (VIFs) were all below the threshold of 5 , revealing no item or construct collinearity (Hair et al., 2013). Discriminant validity was assessed with Fornell and Larcker's (1981) criteria at the measure and construct levels. Inspecting the cross-loadings of items revealed that all indicators loaded highest on their respective construct, and no indicator loaded higher on other than its intended construct. The square root of the AVE was higher than the latent variable correlations allow, suggesting sufficient discriminant validity (Table 1).

Table 1. Average variance extracted (AVE), reliabilities (Cronbach's alphas), composite reliabilities (CR) and correlations matrix of the constructs.

\begin{tabular}{lccccccccc}
\hline & AVE & Alpha & CR & $(1)$ & (2) & (3) & (4) & (5) & $(6)$ \\
\hline Environmental values (2nd order) (1) & .48 & .88 & .90 &. $\mathbf{6 9 4}$ & & & & & \\
Environmental awareness (2) & .65 & .82 & .88 & .873 & $\mathbf{. 8 0 7}$ & & & & \\
Environmental competence (3) & .61 & .79 & .86 & .827 & .511 & $\mathbf{. 7 8 4}$ & & & \\
Corporate stance (4) & .81 & .76 & .89 & .848 & .643 & .612 & $\mathbf{. 8 9 8}$ & & \\
Environmental image (5) & .71 & .79 & .88 & .292 & .370 & .108 & .235 & $\mathbf{. 8 4 2}$ & \\
Perceived value (6) & .63 & .80 & .87 & .197 & .285 & .044 & .141 & .757 & $\mathbf{. 8 2 1}$ \\
\hline
\end{tabular}

The square root of the AVE appears in bold on the diagonal.

a correlation coefficient calculated for a two-item scale.

\subsection{The structural model and testing of the hypotheses}

The structural model and the hypotheses were tested by examining the path coefficients $(\beta)$ and $R^{2}$ values (Table 2). The significance was tested with a bootstrapping procedure with 5,000 replications and no sign change option. All path coefficients in the model were statistically significant except for the path from environmental values to perceived value. This suggests that $\mathrm{H} 2$ and $\mathrm{H} 3$ were supported but $\mathrm{H} 1$ was not supported. Indicated by the $R^{2}$ and $f^{2}$ values, the model explained a considerable amount or variance of the perceived value construct (Cohen, 1988). Country of origin had a negative effect on environmental image, indicating that in contrast to the initial assumption, respondents from companies in lowerincome countries perceived the supplier's environmental image more favorably.

Table 2. Direct effects.

\begin{tabular}{lcc}
\hline & $\beta$ & $f^{2}$ \\
\hline Environmental values $\rightarrow$ Perceived value & $-0.038(\mathrm{~ns})$ & 0.003 \\
Environmental values $\rightarrow$ Environmental image & $0.222^{* *}$ & 0.060 \\
Environmental image $\rightarrow$ Perceived value & $0.711^{* * *}$ & 1.253 \\
Country of origin $\rightarrow$ Environmental image & $-0.359^{* * *}$ & 0.156 \\
& \multicolumn{2}{c}{$R^{2}$} \\
Perceived value & \multicolumn{2}{c}{0.591} \\
\hline
\end{tabular}

${ }^{* * *} p<0.01{ }^{* *} p<0.05$; ns: not significant. 


\section{Discussion}

In this study, two central themes in today's business context were linked: environmental values and value-based approach to supplier relationships. The aim was to explore the construction of environmental values among industrial companies and to explain how environmental issues affect supplier evaluation, particularly customer-perceived value. In this section, the results are discussed and reflected in comparison with previous literature. In addition to theoretical contributions, managerial implications are presented, followed by evaluation of the study's limitations and suggestions for future research.

\subsection{Theoretical contributions}

Before the effect of environmental values on supplier evaluation was tested, the structure of environmental values among industrial companies was explored. As previous literature on the topic was scarce, environmental values were conceptualized as a modification of Dembkowski and Hanmer-Lloyd's (1994) environmental value-attitudes model, which assumes environmental values reside at multiple levels ranging from general beliefs to product-specific attributions. In line with the previous literature (Dembkowski and HanmerLloyd, 1994; Hall, 1989), enviromental values were found to consist of three domains or levels: awareness, competence and corporate stance. Environmental awareness was the key indicator of environmental values, as is expected of environmentally high-impact companies (Banerjee et al., 2003). In addition, our results confirm the significant role of individuals as a key driver of environmental awareness (Drumwright, 1994; Giunipero et al., 2012). In this study, environmental awareness was related to a company's attitude toward monitoring its own environmental effect but also included the actions of influencing others and taking actions to protect the environment. Altogether, the domain of environmental awareness represents the company's normative perception of appropriate environmental behavior (Hall, 1989).

The second dimension of environmental values was named environmental competence, as it reflected the role of environmental values in the company's core business operations and marketing. This factor included tangible elements, such as product and production technology. These dimensions are the source of claims that the company may use when building competitive advantage based on environmental improvements. Whereas previous literature has stated that high-impact companies perceive difficulties in uncovering competitive advantage from a pro-environmental orientation (Banerjee et al., 2003), the results of this study suggest that also high-impact companies acknowledge the potential of environmental competence. The third dimension of environmental values tapped the corporate level stance toward environmental issues. Corporate stance can be considered as the company's general statement about the importance of the topic. Awareness and operational domains explained the largest portion of environmental values whereas corporate stance had a minor emphasis in the latent construct. Results of this study imply that industrial manufacturing companies comprehend environmental values on the operational and attributal levels rather than as an overarching corporate philosophy. This finding is in line with the previous studies that assess environmental values of industrial companies to exist mainly on a reactive level (Kärnä et al., 2003).

The second research question broadened the exploration of environmental values into the supplier relationship dyad. Scholars have provided mixed and even sceptical conclusions 
about the importance of environmental orientation in supply channel management and, especially, supplier evaluation (Ageron et al., 2012; Zhu et al., 2007). Based on previous research, it was assumed that customer's environmental values positively affect their perception of supplier's environmental image and perceived value. In this study, customers' environmental values had no statistically significant effect on the perceived overall value. The lack of a statistically significant effect of environmental values on perceived value lends support to Alexander et al.'s (2014) conclusion that industrial companies consider their environmental values as an ethically laden topic separate from investment decisions that are based on a metrics-oriented, structured evaluation of alternatives. Industrial companies also may associate environmental cost analysis more strongly with the function of environmental management instead of purchasing. In this study, all measures that tapped the perceived cost of environmental improvements had to be dropped from further analyses due to low item loadings. This may be interpreted so that companies consider their environmental value in ethical and normative terms but do not connect environmental prioritization with assessment of investment cost in the case of more environmental and more expensive equipment or other improvements. The exclusion of environmental cost considerations from environmental values and the nonsignificant direct effect of environmental values on perceived customer value (as a function of quality and price) resonate with previous findings that financial performance and environmental purchasing are not directly connected (Blome et al., 2014). Altogether, results of this study support conclusions by Alexander et al. (2014) and Quarshie et al. (2016) that the ethical aspect of environmental concern has not been sufficiently integrated in supply channel management.

However, results show that environmental issues play a significant role in supplier relationships when focus is on the supplier's perceived capabilities in the competitive market. Customers' environmental values had an impact on supplier evaluation so that the stronger environmental values customers had the more positively they rated their supplier's environmental image. Furthermore, a supplier's environmental image had a strong positive effect on perceived value. This result, in the context of existing relationships, corroborates previous findings that a supplier's environmental image contributes to the buyer's environmental aspirations in purchasing (Appolloni et al., 2014). This finding is of specific importance regarding that, in industrial manufacturing, the key supplier of production equipment critically contributes to the customer's environmental capability by offering technologies that enable more environmental processes and outputs. Researchers have shown that an environmental image enhances a self-evaluated competitive performance (Junquera et al., 2012; Larrán Jorge et al., 2015), but this effect is only now replicated in the interfirm setting.

Considering the significant value-adding potential of environmental image, the results provide support for the advantages of a relationship framework to study supplier evaluation (0'Toole and Donaldson, 2002). The value-based approach of this study yields several theoretically relevant insights: First, as suggested by Ulaga and Chacour (2001), the facets and drivers of customer-perceived value should be examined separately in order to gain a meaningful understanding of the interplay of social, functional and economic values in supplier evaluation. In this study, the concept of environmental image as a socially constructing, nonfinancial benefit had a critical role in explaining the transformation of customer environmental values into overall value that was characterized by the functional elements of quality and cost. Second, adopting the concept of customer-perceived value helps integrate the non-financial and financial aspects of the relationship and concern about the environment 
as suggested in the previous literature (Park et al. 2010; Reuter et al., 2012). Third, in the context of industrial supply chains, companies possess dual roles as buyers and suppliers at the same time. The value preferences also have to be understood in this wider supply chain. For example, buyers may utilize their sustainable supplying strategies as a competitive advantage (Roehrich et al., 2014) that adds weight to the n-tier supplier's environmental image as well.

\subsection{Managerial implications}

Researchers have shown that suppliers are unsure and even sceptical about the benefits of environmentally oriented supply strategies (Kirchoff et al., 2016). In this study, industrial customers' value priorities were surveyed in order to increase knowledge about the role of environmental values in supplier evaluation. Results of this study show that regardless of the level of environmental values among customers, an environmentally favorable image of the supplier enhances the customer's overall value perception of a particular supplier. Therefore, even suppliers in industries that have a high impact on the environment may find some competitive advantage in promoting their environmental capabilities, that is, assuming they actually have some. Customer's environmental values did not directly affect perceived value, but the supplier's environmental image was critical in shaping the customer's assessment of the supplier's overall value.

The context of the industrial supply chain necessitates perceiving the customers simultaneously as buyers and as suppliers downstream of their own customers. Bearing this in mind, suppliers may support the implementation of a customer's environmental values into action by offering environmental improvements that the customer, in turn, may use as an environmentally oriented competitive advantage among their own customers and other surroundings. To yield actual reputational outcomes, environmental capabilities must be formulated into clearly communicable attributes that build an environmentally oriented image among customers. Results of this study imply that the benefits that customers perceive in their supplier's environmental capabilities are of a social nature in the context of the supply chain-although they originate from tangible technology and performance-related improvements. As a result, suppliers may add most to customers' value experience by addressing technological and competitive aspects in their customer relationships.

In contrast to the assumption that concern about the environment is more valued and integrated in the operations of companies in developed economies (Dasgupta et al., 2001), the study results indicate that customers located in higher-income economies did not assess their suppliers' environmental image as important as did customers in lower-income economies. This result may reflect the growing pollution problems of developing economies that struggle with the negative side effects of a heavily growing industrial sector. By offering environmental solutions and increasing environmental awareness regardless of the customer's country of origin, industrial suppliers may find a competitive advantage and contribute to the globally common problem of environmental degradation resulting from industrial operations.

\subsection{Limitations and future research suggestions}

This study aimed at exploring and presenting the environmental values structure of industrial business organizations and testing its effect on perceptions about the supplier. Analysis and 
conclusions were based on self-reported, cross-sectional data that were collected in cooperation with supplier companies whose customers were surveyed. This has some implications for assessing the validity and reliability of the study results, especially from the viewpoints of common method bias and social desirability bias. In order to minimize its biasing effect, the common method problem was addressed throughout the research process by following Podsakoff et al.'s (2003) guidelines for procedural and statistical precautions. The constructs were measured with multi-item scales and the items were mixed in the questionnaire. Our survey instrument also included more topics than those presented in this research report which created psychological distance between predictor and criterion variables. A statistical test of common method variance with a procedure suggested by Liang et al. (2007) showed that common method bias was an unlikely contaminator of the results. The effect of socially desirable responding style was also minimized by clearly stating the confidentiality of individual answers (Fisher and Katz, 2000). The social desirability bias is likely lower when informants do not perceive the choice situation as unethical (Chung and Monroe, 2003). Therefore, the aim of data gathering in creating customer knowledge for scientific and managerial interests was emphasized in the cover letter of the survey, relieving the ethical tension that potentially relates to environmental considerations in the business context. A potential threat to the generalizability of the results of this study is the small and selective sample size and the limited scope in the context of certain high-impact industries. However, the dataset included informants from companies in various countries worldwide, which enriches the study coverage of perceptions about the topic across different cultures and economies. The cultural diversity of respondents also contributes to minimizing the effect of social desirability bias, as the socially motivated answering tendency depends on the cultural emphasis of value conformity (Fisher and Katz, 2000).

Measuring organizational values bears some challenges that are related to the context that consists of multiple actors and functions (Agle and Caldwell, 1999). In this study, the explanatory power of the environmental values construct was close to moderate, meriting further research on the topic to develop measures and operationalization that may better conceptualize and explain the environmental values among organizations. However, this study has its merits in the global and cross-cultural coverage of respondents that is not typically obtained in values-related research in the business context. Additionally, the role of cost in environmental considerations and value assessment needs further examination because in this study's explorative analyses, the cost aspect of more environmentally oriented production and investment decisions were not meaningfully related to the constructs of environmental values or perceived value. Future research should therefore deepen the valuebased approach and focus on determining how the perceived cost of environmentally improved solutions affects the transfer of environmental values into supplier relationship outcomes.

Considering the significant effect of suppliers' environmental image on the overall customerperceived value, future research should continue employing the value-based approach to studying supply chains by determining and elaborating the drivers of customer value that consists of financial and non-financial elements.

\section{Conclusions}


This study adopted a novel viewpoint to supply channel management by examining the environmental values structure of industrial companies and the effect of customers' environmental values on overall value of the supplier. The results showed that industrial customers' environmental values are a multi-dimensional and hierarchical construct that comprises three dimensions: awareness, competence and corporate stance. This study confirmed environmental awareness as the main building block of concern for the environment whereas the aspect of cost of environmental improvements was absent. The aim of this study was not to assess the genuineness of reported environmental values among industrial companies; instead, the goal was to demonstrate the effect of customer's selfreported environmental values on perceived overall value of the supplier. Based on this result, it may be argued that environmental values of industrial companies are distinguished from economic considerations, and that the conflict between environmental and economic values remains unsolved or even unformulated. Despite the lack of a direct link between environmental values and perceived value, the results of this study confirm the link between environmental values and supplier evaluation. Customers who possessed stronger environmental values also rated their suppliers' environmental image more favorably. Furthermore, suppliers' environmental image contributed strongly to customers' overall value assessment of the supplier. This study adopted the customer's viewpoint to assessing supplier capabilities and image which is a new contribution to the topic. The study results support the usefulness of a value-based approach to studying supplier relationships and the integration of economic and environmental considerations as providing suppliers with a competitive advantage. For managers, to maintain a favorable position in a competitive market, industrial suppliers should actively address environmental issues and communicate their environmental capability to customers as this effort is valued as an enhanced environmental image and higher customer-perceived value.

Funding: This work was supported by the Finnish Funding Agency for Technology and Innovation (TEKES), the Finnish Cultural Foundation, and the Foundation for Economic Education (Finland). 


\section{References}

Ageron, B., Gunasekaran, A., Spalanzani, A., 2012. Sustainable supply management: An empirical study. International Journal of Production Economics. 140(1), 168-182.

Agle, B.R., Caldwell, C.B., 1999. Understanding values in business: a level of analysis framework. Business \& Society. 38, 326-387.

Alexander, A., Walker, H., Naim, M., 2014. Decision theory in sustainable supply chain management: a literature review. Supply Chain Management: An International Journal, 19(5/6), 504-522. DOI http://dx.doi.org/10.1108/SCM-01-2014-0007

Amores-Salvadó, J., Martín-de Castro, G., Navas-López, J.E., 2014. Green corporate image: moderating the connection between environmental product innovation and firm performance. Journal of Cleaner Production. 83, 356-365.

Andersen, P.H., Ellegaard, C., Kragh, H., 2016. I'm your man: How suppliers gain strategic status in buying companies. Journal of Purchasing and Supply Management. 22(2), 72-81.

Anderson, J.C., Gerbing, D.W., 1988. Structural equation modeling in practice: A review and recommended two-step approach. Psychological Bulletin. 103(3) 411-.

Anderson, J.C., Thomson, J.B.L., Wynstra, F., 2000. Combining value and price to make purchase decisions in business markets. International Journal of Research in Marketing. 17, 307-329.

Andreassen, T.W., Lindestad, B., 1998. The effect of corporate image in the formation of customer loyalty. Journal of Service Research. 1(1), 82-92.

Appolloni, A., Sun, H., Jia, F., Li, X., 2014. Green Procurement in the private sector: a state of the art review between 1996 and 2013. Journal of Cleaner Production. 85, 122-133.

Armstrong, J.S., Overton, T.S., 1977. Estimating nonresponse bias in mail surveys, Journal of Marketing Research. 14(3), 396-402.

Banerjee, S.B., 2001. Corporate environmental strategies and actions. Management Decision. 39, 36-44. DOI: 10.1108/EUM0000000005405

Banerjee, S.B., Iyer E.S., Kashyap R.K., 2003. Corporate environmentalism: antecedents and influence of industry type. Journal of Marketing. 67, 106-122.

http://www.jstor.org/stable/30040526

Bell, S.J., Auh S., Smalley K., 2005. Customer relationship dynamics: service quality and customer loyalty in the context of varying levels of customer expertise and switching costs. Journal of the Academy of Marketing Science. 33, 169-183. DOI:

$10.1177 / 0092070304269111$ 
Björklund, M., 2011. Influence from the business environment on environmental purchasing-Drivers and hinders of purchasing green transportation services. Journal of Purchasing and Supply Management. 17(1), 11-22.

Blome, C., Hollos, D., Paulraj, A., 2014. Green procurement and green supplier development: antecedents and effects on supplier performance. International Journal of Production Research. 52(1), 32-49.

Cantor, D.E., Morrow, P.C., McElroy, J.C., Montabon, F., 2013. The role of individual and organizational factors in promoting firm environmental practices. International Journal of Physical Distribution \& Logistics Management. 43(5/6), 407-427

Cheng, J.-H., Yeh, C.-H., Tu, C.-W., 2008. Trust and knowledge sharing in green supply chains. Supply Chain Management: an International Journal. 13, 283-295.

Chung, J., Monroe, G. S., 2003. Exploring social desirability bias. Journal of Business Ethics, 44(4), 291-302.

Ciavolino, E., Dahlgaard, J.J., 2007. ECSI-customer satisfaction modelling and analysis: a case study. Total Quality Management. 18(5), 545-554.

Closs, D.J., Speier, C., Meacham, N., 2011. Sustainability to support end-to-end value chains: the role of supply chain management. Journal of the Academy of Marketing Science. 39(1), 101116.

Cohen, J., 1988. Statistical power analysis for the behavioral sciences, second ed. Erlbaum, Hillsdale New Jersey.

Dasgupta, S., Mody, A., Roy, S., Wheeler, D., 2001. Environmental regulation and development: A cross-country empirical analysis. Oxford development studies. 29(2), 173-187.

Dembkowski, S., Hanmer-Lloyd, S., 1994. The environmental value-attitude system model: a framework to guide the understanding of environmentally-conscious customer-behavior. Journal of Marketing Management. 10, 593-603.

Drumwright, M.E., 1994. Socially responsible organizational buying: Environmental concern as a noneconomic buying criterion. Journal of Marketing. 58, 1-19.

Fang, E., Palmatier. R.W., Evans, K.R., 2008. Influence of customer participation on creating and sharing of new product value. Journal of the Academy of Marketing Science. 36, 322-336.

Fisher, R.J., Katz, J.E., 2000. Social Desirability Bias and the Validity of Self-Reported Values. Psychology \& Marketing. 17, 105-120.

Flint, D.J., Woodruff, R.B., Gardial, S.F., 2002. Exploring the phenomenon of customers' desired value change in a business-to-business context. Journal of Marketing. 66, 102-117.

Fornell, C., Larcker, D.F., 1981. Evaluating structural equation models with unobservable variables and measurement error. Journal of Marketing Research. 18(1), 39-50. 
Giunipero, L.C., Hooker, R.E., Denslow, D., 2012. Purchasing and supply management sustainability: Drivers and barriers. Journal of Purchasing and Supply Management. 18(4), 258-269.

Goh, S.K. and Balaji, M.S., 2016. Linking green skepticism to green purchase behavior. Journal of Cleaner Production. 131, 629-638. DOI: http://dx.doi.org/10.1016/j.jclepro.2016.04.122

Green Jr, K.W., Zelbst, P.J., Meacham, J., Bhadauria, V.S., 2012. Green supply chain management practices: impact on performance. Supply Chain Management: An International Journal. 17(3), $290-305$.

Hall, J., 1989. Values, the key to business in 1990 and beyond. Journal of Marketing Management. 5(2), 123-132.

Hall, J., 2000. Environmental supply chain dynamics. Journal of Cleaner Production. 8(6), 455471.

Hair Jr., J.F., Hult, G.T.M., Ringle, C.M., Sarstedt, M., 2013. A Primer on Partial Least Squares Structural Equation Modeling (PLS-SEM), Sage, Los Angeles.

Hanson, J.D., Melnyk, S.A., Calantone, R.J., 2004. Core values and environmental management. Greener Management International. 46, 29-40.

Heikkurinen, P., Bonnedahl, K.J., 2013. Corporate responsibility for sustainable development: a review and conceptual comparison of market-and stakeholder-oriented strategies. Journal of Cleaner Production. 43, 191-198.

Junquera, B., del Brío, J.Á., Fernández, E., 2012. Clients' involvement in environmental issues and organizational performance in businesses: an empirical analysis. Journal of Cleaner Production. 37, 288-298.

Kirchoff, J. F., Omar, A., Fugate, B. S., 2016. A Behavioral Theory of Sustainable Supply Chain Management Decision Making in Non-exemplar Firms. Journal of Supply Chain Management. 52(1), 41-65.

Kovács, G., 2008. Corporate environmental responsibility in the supply chain. Journal of Cleaner Production. 16(15), 1571-1578.

Kärnä J, Hansen E, Juslin H., 2003. Social responsibility in environmental marketing planning. European Journal of Marketing. 37, 848-871. DOI: 10.1108/03090560310465170

Kärnä, J., Juslin, H., Ahonen, V., Hansen, E., 2001. Green advertising. Greenwash or a true reflection of marketing strategies?. Greener management international. 6, 59-70.

Laari S., Töyli J., Ojala L., 2016b. Supply chain perspective on competitive strategies and green supply chain management strategies. Journal of Cleaner Production. DOI: 10.1016/j.jclepro.2016.09.114. 
Laari, S., Töyli, J., Solakivi, T. and Ojala, L., 2016a. Firm performance and customer-driven green supply chain management. Journal of Cleaner Production. 112, 1960-1970.

Larrán Jorge, M.L., Madueño, J.H., Martínez-Martínez, D., Sancho, M.P.L., 2015. Competitiveness and environmental performance in Spanish small and medium enterprises: is there a direct link? Journal of Cleaner Production. 101, 26-37.

Ledden, L., Kalafatis, S.P., and Samouel, P., 2007. The relationship between personal values and perceived value of education. Journal of Business Research. 60, 965-974.

Lee, S.Y. and Rhee, S.-K., 2007. The change in corporate environmental strategies: a longitudinal empirical study. Management Decision. 45, 196-216.

Liang, H., Saraf, N., Hu, Q., Xue, Y., 2007. Assimilation of enterprise systems: The effect of institutional pressures and the mediating role of top management. MIS Quarterly. 31(1), 5987.

Lindgreen, A., Antioco, M., Harness, D., Van der Sloot, R., 2009. Purchasing and marketing of social and environmental sustainability for high-tech medical equipment. Journal of Business Ethics. 85(2), 445-462.

Liobikienè, G., Juknys, R., 2016. The role of values, environmental risk perception, awareness of consequences, and willingness to assume responsibility for environmentally-friendly behaviour: the Lithuanian case. Journal of Cleaner Production. 112, 3413-3422.

Mueller, M., Gomes dos Santos, V., Seuring, S., 2009. The contribution of environmental and social standards towards ensuring legitimacy in supply chain governance. Journal of Business Ethics. 89, 509-523.

O’Toole, T., Donaldson, B., 2002. Relationship performance dimensions of buyer-supplier exchanges. European Journal of Purchasing \& Supply Management. 8(4), 197-207.

Park, J., Sarkis, J., Wu, Z., 2010. Creating integrated business and environmental value within the context of China's circular economy and ecological modernization. Journal of Cleaner Production. 18(15), 1494-1501.

Paulraj, A., 2009. Environmental motivations: a classification scheme and its impact on environmental strategies and practices. Business Strategy and the Environment. 18(7), 453468.

Podsakoff, P.M., MacKenzie, S.B., Lee, J.-Y., Podsakoff, N.P., 2003. Common method biases in behavioral research: a critical review of the literature and recommended remedies. Journal of Applied Psychology. 88(5), 879-903.

Preuss, L., 2001. In dirty chains? Purchasing and greener manufacturing. Journal of Business Ethics. 34(3-4), 345-359. 
Quarshie, A. M., Salmi, A., Leuschner, R., 2016. Sustainability and corporate social responsibility in supply chains: The state of research in supply chain management and business ethics journals. Journal of Purchasing and Supply Management. 22(2), 82-97.

Rao, P., Holt, D., 2005. Do green supply chains lead to competitiveness and economic performance? International journal of operations \& production management. 25(9), 898916.

Reuter, C., Goebel, P., Foerstl, K., 2012. The impact of stakeholder orientation on sustainability and cost prevalence in supplier selection decisions. Journal of Purchasing and Supply Management. 18(4), 270-281.

Ringle, C.M., Wende, S. and Becker, J., 2014. Smartpls 3, Hamburg: SmartPLS. http://www.smartpls.com (accessed 14.07.14).

Roehrich, J.K., Grosvold, J., Hoejmose, S.U., 2014. Reputational risks and sustainable supply chain management: Decision making under bounded rationality. International Journal of Operations \& Production Management. 34(5), 695-719.

Schwartz, S. H., 1992. Universals in the content and structure of values: theoretical advances and empirical tests in 20 countries. Advances in Experimental Social Psychology. 25, 1-65.

Severo, E.A., de Guimarães, J.C.F., Dorion, E.C.H., Nodari, C.H., 2015. Cleaner production, environmental sustainability and organizational performance: an empirical study in the Brazilian Metal-Mechanic industry. Journal of Cleaner Production. 96, 118-125.

Smith, N.C., 2009. Bounded goodness: marketing implications of Drucker on corporate responsibility. Journal of the Academy of Marketing Science. 37, 73-84.

Sweeney, J.C., Soutar, G.N., 2001. Consumer perceived value: the development of a multiple item scale. Journal of Retailing. 77(2), 203-220.

Ulaga, W., Chacour, S., 2001. Measuring customer-perceived value in business markets: a prerequisite for marketing strategy development and implementation. Industrial marketing management. 30(6), 525-540.

Ulaga, W., Eggert, A., 2006. Value-based differentiation in business relationships: gaining and sustaining key supplier status. Journal of Marketing. 70, 119-136.

Vinson, D. E., Scott, J. E., Lamont, L. M., 1977. The role of personal values in marketing and consumer behavior. Journal of Marketing, 44-50.

Woodruff, R.B., 1997. Customer value: the next source for competitive advantage. Journal of the academy of marketing science. 25(2), 139-153.

World Bank (2014). Country and Lending Groups. https://datahelpdesk.worldbank.org/knowledgebase/articles/906519\#High_income (accessed 14.07.14). 
Yen, Y.X., Yen, S.Y., 2012. Top-management's role in adopting green purchasing standards in high-tech industrial firms. Journal of Business Research. 65(7), 951-959.

Zeithaml, V., 1988). Consumer perceptions of price, quality, and value: a means-end model and synthesis of evidence. Journal of Marketing. 52, 2-22.

Zhao, X., Zhao, Y., Zeng, S., Zhang, S., 2015. Corporate behavior and competitiveness: impact of environmental regulation on Chinese firms. Journal of Cleaner Production. 86, 311-322.

Zhu, Q., Sarkis. J., Geng, Y., 2005). Green supply chain management in China: pressures, practices and performance. International journal of operations \& production management. 25, 449-468.

Zsóka, Á.N., 2008. Consistency and "awareness gaps" in the environmental behaviour of Hungarian companies. Journal of Cleaner Production. 16(3), 322-329. 


\section{APPENDIX: List of measures}

\begin{tabular}{|l|c|c|}
\hline & Mean & $\begin{array}{l}\text { Factor } \\
\text { loading }\end{array}$ \\
\hline Environmental values (seven-point scale "strongly disagree-strongly agree") & & \\
\hline Environmental awareness & & \\
\hline Our company's employees have a strong interest in green values & 5.03 & .84 \\
\hline Environmental issues have had a strong impact on our distribution channels & 4.66 & .82 \\
\hline We are well aware of all the environmental effects of our production & 5.64 & .79 \\
\hline Our company takes actions to preserve natural resources & 5.39 & .78 \\
\hline Environmental competence & & \\
\hline Our company uses 'environmentally friendly' claims in its marketing communications & 5.38 & .83 \\
\hline Our company's disposal methods yield environmental benefits & 5.36 & .79 \\
\hline Our products are environmentally friendly & 5.52 & .77 \\
\hline Our production technology is more environmentally friendly than our competitors' & 4.88 & .74 \\
\hline Corporate stance & & \\
\hline $\begin{array}{l}\text { Environmental issues have had a strong impact in our company's values and } \\
\text { philosophy }\end{array}$ & 5.42 & .90 \\
\hline $\begin{array}{l}\text { In our strategic product decisions, we place much emphasis on the environmental } \\
\text { friendliness of our products and solutions }\end{array}$ & 5.48 & .90 \\
\hline & & \\
\hline Environmental image & & \\
\hline Compared to competitors...(seven-point scale "strongly disagree-strongly agree") & & \\
\hline $\begin{array}{l}\text { X offers better products and solutions to improve our environmental performance } \\
\text { than its competitors do }\end{array}$ & 4.55 & .90 \\
\hline X is known to be environmentally conscious & 4.76 & .89 \\
\hline $\begin{array}{l}\text { X actively communicates solutions for improving the environmental performance of } \\
\text { our production }\end{array}$ & 4.21 & .72 \\
\hline & & \\
\hline Perceived value & & \\
\hline Compared to competitors...(seven-point scale "strongly disagree-strongly agree") & 5.61 & .86 \\
\hline The products/services provided by X are of higher quality & 5.25 & .82 \\
\hline X is a reliable supplier & 3.93 & .81 \\
\hline X's products and solutions perform consistently & 3.99 & .68 \\
\hline X's price is reasonable in relation to the delivered outcome & & \\
\hline
\end{tabular}


Highlights

Environmental values and customer-perceived value in industrial supplier relationships

- Value-based approach to supplier evaluation is adopted and tested

- Environmental values comprise of awareness, competence and corporate stance

- Customer's environmental values have an effect on supplier image

- Supplier's environmental image influences customer-perceived value

- Competitive advantage among customers is enhanced by an environmental image 